\title{
Globalizing the savage: From stadial theory to a theory of luxury in late- I 8th-century Swedish discussions of Africa
}

History of the Human Sciences

$1-15$

(C) The Author(s) 2019

Article reuse guidelines: sagepub.com/journals-permissions DOI: I0.I I77/0952695| | 9836590 journals.sagepub.com/home/hhs

@SAGE

\author{
Hanna Hodacs \\ Dalarna University, Sweden
}

\section{Mathias Persson \\ Uppsala University, Sweden; University of Johannesburg, South Africa}

\begin{abstract}
This article examines the effects of globalization on changing notions of the 'savage'. We compare discussions taking place in different contexts in the late 18th century concerning two Swedish scholars and travellers to Africa: Anders Sparrman (1748-1820), a naturalist and Linnaean disciple, and Carl Bernhard Wadström (I746-99), an engineer and economist. Both moved in Swedish Swedenborgian circles, and both became involved in the British abolitionist movement. Nevertheless, their images of African 'Others' diverged in crucial respects, reflecting differences in their ideological outlooks, institutional affiliations, and understandings of how the world was changing. More specifically, we argue that the perception of global change brought about by a new economic framework of production and consumption provides a key for reading and comparing Wadström's and Sparrman's texts. Comparing their divergent uses of 'savagery', the article also highlights the versatility of the savage as a tool for presenting distant parts of the world to a domestic audience.
\end{abstract}

\section{Corresponding author:}

Mathias Persson, Department of Economic History, Uppsala University, Box 513, Uppsala, Uppland 75I 20, Sweden.

Email: mathias.persson@ekhist.uu.se 


\section{Keywords}

civilization, globalization, savage, Sparrman, Wadström

\section{Introduction}

Expanding trade in the 18th century connected different parts of the world on a new scale. This was largely driven by the growing consumption of globally sourced goods in Europe. At the same time, Europe's method of colonial expansion changed as older empires and trading nations, notably the Spanish, Portuguese, and Dutch empires, declined, and those of France and especially Britain came into ascendancy. Connecting these two global dynamics was an adaptable conception of savagery, which could be used to present human differences to European audiences, as the other articles in this issue demonstrate.

This article examines two discrete late-18th-century Swedish interpretations of the savage in relation to globalization. Our reasons for doing so are to illustrate both how pervasive European notions of savagery were in the 18th century, and how involved Swedish travellers and intellectuals were in their application and dissemination. These developments are epitomized by the natural historian and Linnaean disciple Anders Sparrman (1748-1820) and the economist and engineer Carl Bernhard Wadström (1746-99). ${ }^{1}$ Sparrman and Wadström travelled to West Africa together in the 1780s as participants in a scientific expedition influenced by Swedenborgianism and promoted by King Gustav III (1746-92), who sought covertly to establish a colony there, in order to involve Sweden in the lucrative triangular trade (Nyberg, 2012: 26-7; Ogden, 2012: 146; Weiss, 2016: 25-48). Named after the Swedish scientist and theologian Emanuel Swedenborg (1688-1772), Swedenborgian evangelism anticipated the establishment of a New Church receptive to what it considered the superior spiritualism of the 'African race'. Although this mission failed, the expedition did result in Sparrman and Wadström's becoming involved with the British abolitionist movement. On returning from Africa, the pair stopped in London and testified before Parliament on their experiences of the transatlantic slave trade (Ogden, 2012: 148-53, 155; Rönnbäck, 2013: 425, 427, 438). Nevertheless, their images of African 'Others' diverged in crucial respects, reflecting both differences in their ideological outlooks and institutional affiliations, and different understandings of how the world was changing. More specifically, we argue that the globalization of trade and its consequences for production and consumption provide a key for reading and comparing Sparrman's and Wadström's texts. Highlighting their diverse uses of 'savagery' vis-a-vis different audiences - a national Swedish one and a pan-European one - this article also demonstrates the versatility of the savage as a tool for depicting distant parts of the world, their histories and their futures.

The globalization driven by Europe in the 18th century involved increased exposure to different cultures, which metropolitan observers sought to interpret. Two dominant models were provided by French and Scottish luminaries, respectively, each premised on a particular understanding of human development. While the French scholars tended to write 'a history of the human mind', the Scots framed mental development with a 'more empirical, material, and stadial' theory (Palmeri, 2008: 6). Stadial theory, on which we 
focus here, has aptly been described as an 'Enlightenment theory of sociocultural evolution' that imagined a progression in stages, generally four: from hunting and gathering to sedentary pastoralism, then to agriculture, and finally to commercial civilization. The first of these stages was sometimes merged with the second, and the third with the fourth, resulting in a two-stage model. Another common approach to social development subdivided humankind into three stages - savages, barbarians and civilized peoples - which corresponded, in turn, to hunting and gathering, pastoralism, and farming and commerce. Irrespective of the exact number of imagined stages, human societies were afforded different levels of material and cultural progress, defined by their modes of subsistence, and subjected to a singular, universal, and hierarchical pattern of advancement (Ellingson, 2001: 159; Palmeri, 2008: 6; Sebastiani, 2013; Wolloch, 2011: 252-4).

At the bottom of this grand ladder dwelled the vagrant hunting and gathering savages, those living in a state of nature who predated civil society and stood at the threshold of social time (Buchan and Heath, 2006: 11-4; Pagden, 1993: 13-14). Denied a history as well as property rights, these uncivilized humans were construed in relation to cultivated Europeans, whose polar opposite they were thought to be. 'Savagery' and 'civilization' (or 'enlightenment') were integral to Europe's colonial projects, and were performative as well as descriptive terms (Buchan and Heath, 2006: 6-9, 13-14; Ellingson, 2001: 219-20). As Buchan and Andersson Burnett point out in this issue, the savages of stadial theory can be seen as a mental corollary of Europe's 18th-century globalization and colonial expansion. Savagery provided an adaptable rationale for conceiving of other peoples as inferior human brutes with limited rights of ownership of the land they inhabited.

While Africa and its inhabitants could be viewed in a positive light, as exponents of Arcadian bliss and a capacity for virtuousness and art, 18th-century Europe mostly imagined them in negative terms. Africans were cast as pre-civilized versions of Europeans and attributed an ingrained inertia that gave rise to ignorance, idleness, lack of development, and susceptibility to lower passions, characteristics that simultaneously pertained to savages in general (Jacques, 1997: 200-1, 204-6). The 'ignoble' savage was much more in vogue than its 'noble' counterpart, whose historical conceptual validity has, incidentally, been called into question (Campbell, 1980: 47-8, 56; Ellingson, 2001).

The Scottish Enlightenment was also the context in which central doctrines in early modern political economy were articulated. Adam Smith's Wealth of Nations (1776) and his ideas about the role of commerce and international trade in promoting economic growth and human progress were central to the formulation of stadial theory (Meek, 1976). It was also the text that put paid to a centuries-long debate about the role of luxury in modern society. Smith defined luxury in relativist terms, thereby sidestepping the normative discussion dominating much of the 18th century (Hont, 2006: 379-80; Roberts, 1998: 24). The centrality of luxury as a topic among Enlightenment philosophers reflected the profound changes to consumption in cosmopolitan Europe. Long considered a source of enervating corruption in European thought, luxury had by the 18 th century become more ambiguous. The earlier emphasis on vice was challenged by new ideas linking 'modern' luxuries to refinement, taste, and the expansion of global trade (Berg and Eger, 2003: 7-27). Luxury became the prism through which the history of previous states and the organization of present and future European societies could be 
seen. 'Traditionalists' tended to associate luxury with the fall of empires, inequality, the degradation of the countryside, and numerous negative personal characteristics ultimately threatening the survival of the state. 'Modernists' saw luxury as a catalyst for progress, disagreeing only on how to harness it in order to optimize its effects (Hont, 2006: 380-2). Human historical progress, of the kind envisaged by stadial theorists such as Smith, was thus driven by new patterns of economic production and consumption to which luxury was indispensable. This same complex of ideas can be used to interpret Sparrman's and Wadström's writings, and especially their accounts of Africa as a prime repository of savagery for the 18th-century European mind, though their interpretations diverged.

\section{Sparrman and static stadialism}

Sparrman was a fellow of the Royal Swedish Academy of Sciences. Founded in 1739, during the so-called Age of Liberty, the Academy did not only constitute an intellectual powerhouse, but was also a political body. It was one significant instance of a wider effort by the ruling Hat Party to improve the standing of the realm by fostering art, literature, and science, and it acted as an extended arm of the authorities (Laine, 1998: 195-6; Widmalm, 1990: 57). The situation remained essentially unchanged after Gustav III's coup d'etat in 1772, as the royal academies came to serve the new regime and formed part of the institutional landscape of the state (Alm, 2002: 114; Tandefelt, 2008: 99-100). The output of the Royal Academy of Sciences was therefore by no means inconsequential. Moreover, it provided a channel for international communication, as many texts produced by the Academy and its fellows were translated into other European languages.

In October 1778, Sparrman gave a speech at the Academy that summarized his extensive travels to the Southern Hemisphere earlier in the 1770s, part of which involved acting as assistant to Johann Reinhold (1729-98) and Georg Forster (1754-94) on Captain James Cook's Resolution voyage to the Pacific (Sörlin and Fagerstedt, 2004: 159-60). Sparrman's speech was subsequently printed as Oration on the Growth and Utility That the Sciences in General, Particularly Natural History, Have Already Attained and Could Further Attain Through Investigations in the South Seas (Sparrman, 1778). The abbreviated travel narrative belonged to the subgenre of presidential orations, which were held by the chairmen when their three-month tenures came to an end and which regularly dealt with economic and political issues. They were almost as popular as the Academy's widely read Proceedings, Kungliga Vetenskaps Academiens Handlingar (Lindroth, 1967: 38-9, 363; Wargentin, 1764: 112).

Sparrman's speech was a much more incisive and ideologically charged affair than his published travelogue, one in which cultural relativism played a prominent role (Nyberg, 2012: 25). The presidential orations functioned as vehicles for more or less officially sanctioned political beliefs, not least those pertaining to non-European lands and their denizens (Persson, 2017: 138). Sparrman's exposition on the South Seas was firmly embedded in stadial theory and the discourse of savagery and civilization. He took a substantial interest in peoples he referred to as 'savages'. He initially stated that his travels entailed constant encounters with alien languages and that he had 'often been 
forced to babble forth the unknown ways of speaking of Indians and Savages, sometimes with the most peculiar sounds' (Sparrman, 1778: 4).

Sparrman established that the study of nature was a duty, and that reason and improvement were inculcated in the human mind:

The exploration and investigation of nature is both a useful and an obligatory nature-based purpose for our species. As we have been gifted by nature with the seed of reason, we are also obliged by nature not to stifle, but to cultivate it; and consequently also obliged to improve the condition of our species in all regards. (Sparrman, 1778: 5) ${ }^{2}$

In line with this, Sparrman claimed that all humans, for their own sake and that of others, were required to unearth and utilize what nature had to offer. This was in part a divine mandate, for God had made it possible for plants to be introduced into new locales by humans, enabling 'the cultivation and embellishment of all of growing Nature in every part of the World'. Humankind was juxtaposed with the oblivious animals, while the world was envisaged as a hierarchical 'chain of Nature'. The latter formulation can be related to the ancient idea of a great chain of being, a universal order of precedence that extended from dead matter to God, and which was characterized by optimal plenitude and an array of levels of creation (Sparrman, 1778: 5, 13-4, 18; Lovejoy, 1936). Sparrman's teacher and mentor, the renowned Uppsala botanist Carl Linnaeus (1707-78), took this gradated hierarchy for granted and applied it to the human species (Sloan, 1995: 123, 126).

In Sparrman's opinion, those who did not enhance their rational capacity and the state of humanity were behaving incorrectly: 'although some Humans can reach an advanced age [living] as Savages [Vildar] and Beasts [Vildjur], they are nonetheless erring, since they do not live in keeping with what is appropriate for [the] sensible and civilized'. In small communities - families or flocks - humans lacked mutual assistance and were ultimately incapable of recognizing 'some of the needs of humankind', which led to mismanagement of industry and agriculture, to scarcity and starvation, and to the dulling of the body and the mind. These views clearly echo the Edinburgh historian William Robertson's (1721-93) estimation of Amerindians in his History of America (1777); Sparrman was indeed familiar with Robertson and the Scottish Enlightenment, whose stadialism he married to Linnaean taxonomy (Andersson Burnett and Buchan, 2018: $163,173)$. In this miserable condition, humans would spend their days fulfilling the most rudimentary material wants, sparing no time for enlightening sciences or comfortgenerating crafts. However, savages could be subjected to useful anthropological reflections that put humanity into perspective, 'in particular... what has impaired and improved the Peoples' (Sparrman, 1778: 5, 18-19).

Sparrman offered what he considered to be evidence to illustrate and underscore his theoretical points. Nomads drifted aimlessly and could not count on stable sustenance; neither they nor their livestock got enough nourishment and wildness reigned supreme, as in the case of the southern African Xhosa ('Kaffirs') and Khoikhoi ('Hottentots'). The predicament of hunting populations was especially bad, he argued, since they frequently became dispersed due to the movement of their game and an unceasing struggle for food, which made them run away from 'their own fierce Brothers'. The precarious food supply 
meant that they could not settle down, because hunger and their supposedly savage manner of providing for themselves would force them to leave before they were able to create towns or larger societies. The consequences of this way of life were dire, as the San ('Boshies-Men') in southern Africa and the sparse population of Tierra del Fuego in South America demonstrated: 'They deteriorate to Savages, in effect beasts, until they hardly speak a language that can attest to a thinking being' (Sparrman, 1778: 19-20).

Fishing 'nations' were equally inept at developing civilization, since their uncertain means of subsistence made it difficult for them to practice crafts and farming. They, too, lacked towns and societies, and took on a brutish appearance: 'They are forced to erect their huts on desolate beaches, and themselves become elusive and vagrant, like the swimming animals which they pursue in an Element without borders'. Here, Sparrman invoked the Māori, 'the Savages in New Zealand', who presented him with 'the most horrid testimonies' to the evils this mode of living could bring about, in the form of bloodstained shores with remains of devoured human bodies. In addition, he declared that persistent storms could drive fishing peoples to consume a variety of fern root that ranked among the worst foodstuffs, and which was 'so much more unbecoming for creatures animated by a rational soul, as the ape species probably nowhere makes use of such wretched nourishment' (Sparrman, 1778: 20-1). The actions of these humans thus placed them beneath animals, which knew how to avoid the unsuitable plant.

Sparrman's account of the misery that befell nomadic, hunting, and fishing peoples formed the basis for his denunciation of a specific sort of teaching: 'May such deplorable nuisances lead certain warped Philosophers from a delusion disgraceful and dangerous for all humanity, that is, that the civilized state would be less blissful than the savage one!' Considering that an analogous criticism had been directed at the 'famous citizen of Geneva' less than a year before in a presidential oration by the chemist Torbern Bergman (1735-84), it is reasonable to assume that Sparrman was aiming his attack, at least in part, at the Genevan philosopher Jean-Jacques Rousseau (1712-78). ${ }^{3}$ Sparrman considered Rousseau misguided in critiquing civic life by elevating the simplicity of supposed savages, and so Sparrman's was a triumphal model of stadial historical progress. Human beings united by language and sentiment, he argued, could combine to form mighty societies, wherein they learned to tame the animals as well as 'their own savagery, and [to] bridle each other's inhumanity'. This brought about increased welfare and order, which gave rise to diligence and every other civic virtue that fostered the sciences, crafts, and agriculture. The next step was to construct towns and places of worship, and to gain access to the oceans and circumnavigate the world; 'in short, to constitute polite Humans and civilized Peoples' (Sparrman, 1778: 21-2). The stadial character of Sparrman's thinking is clear; savagery gave way to farming, which gave way to global commerce befitting a civilized era.

Sparrman did consider the possibility of transforming supposed savages into polite peoples, who could eventually make scientific contributions and repay the Europeans with useful discoveries (Sparrman, 1778: 22-7). In Sparrman's vision, however, Europe's advanced civilization bestowed a superiority that he presented rhetorically by portraying peoples he deemed less advanced as lacking the European 'gift' of civilization: 
We Europeans ... who call ourselves Civilized, and who have experienced the noblest proof of as well as [gained] advantage from savage Patagonians' civilized hearts, but thereby also witnessed their and more impolite Nations' ruin, so to speak, with regard to human necessities and enlightenment, should we not so much sooner, and to general utility for humanity, and the expansion of knowledge and the Sciences, convey to these Brothers a human right that nature has intended for our kind? (ibid.: 26)

Sparrman also speculated that Providence had reserved Patagonia's epistemic treasures for those who performed beneficial deeds there, and that nature had furnished savages with advantages that attracted 'at least self-serving visits by strangers, and thus occasionally knowledge and enlightenment' (Sparrman, 1778: 26-7). Self-interest could bring about a common good and the civilizing mission be made lucrative for the civilizers.

In contrast with his oration, Sparrman's travelogue - typified by the volume on Africa, the most popular and influential of the three volumes at the time - exhibited overall a more complex and ambivalent approach to the so-called savages. Here, he depicted them in more positive terms, and the conduct of European colonists was condemned repeatedly (Nyberg, 2012: 18, 24-5). Nevertheless, the dichotomy of civilization and savagery formed a fundamental assumption underlying the entire narrative, perhaps most clearly expressed in his identification of Europe with 'the civilized world' and of the areas beyond it with darkness and savagery (Sparrman, 1783: i, 103). Stadial theory featured at various points, as when Sparrman contrasted what he considered to be 'unrestrained and rude Hottentot[s]' with 'those who have raised Arts and Sciences to a considerable height'. To give another example, a portion of the San people were said to be more polite and to label themselves as good; according to Sparrman, this was most likely due to their practice of at least limited cattle breeding, unlike their hunting and gathering kin (Sparrman, 1778: 198, 411, 543). William Beinart neatly sums up Sparrman's subtler stance when he points out that the Swedish traveller 'could certainly be overbearing and reflected contemporary European ideas of different gradations of "savageness", but that he still 'often adopted an explicitly humane position on some of the social ills of the [Cape] Colony' (Beinart, 1998: 786). Ambiguities and intricacies were likewise symptomatic of the overarching European discourse on savagery, since the 'Other' served as a screen for both positive and negative projections; for instance, Africans 'were reduced to a monolithic substance that mirrored whatever qualities Europe was assumed to possess, fear, or secretly desire' (Campbell, 1980: 48-52, 578; Crais, 1991: 258-9; Jacques, 1997: 200-1).

The predominantly Eurocentric tenor of Sparrman's presidential oration can be explained by its very setting, the Royal Academy of Sciences under the autocratic monarch Gustav III, who for many years pursued an extra-European territory to benefit his realm economically and endow it with the trappings of a colonial power. In 1784, Sweden finally acquired the Caribbean island of Saint Barthélemy from France (Sprinchorn, 1923: 142-55; Waller, 1953; Weiss, 2013: 275). The royal ambitions were echoed in the republic of letters, and several of the Academy's chairmen held views similar to those expressed by Sparrman (see, for instance, Nordenskiöld, 1776; Qvist, 1776).

Although Sparrman embraced the potential of savages to reach the polite stage, his assertions in this vein did not contain any suggestion of immediacy. The civilizing of the 
non-European 'Others' lay in the future, and was an abstract rather than a practical issue. In this respect as well, Sparrman brings to mind contemporary Scottish intellectuals, who 'cautioned that progress occurred slowly and mysteriously' (Lucas, 2000: 184). Moreover, the chiefly negative representations of non-European peoples, moored in the polarity between 'civilization' and 'savagery', served to reinforce Sparrman's statist tone. The rootlessness, inefficient modes of sustenance, and dearth of enlightenment and comfort displayed by the savages implicitly put any substantial advancement in doubt, especially when juxtaposed with the blessings of civilization, the arts and the sciences. $^{4}$

\section{Wadström, luxury and the globalization of trade}

Bernard Wadström and his two volume Essay on Colonization, Particularly Applied to the Western Coast of Africa (1794-95) were also closely associated with members of the Royal Swedish Academy of Sciences. Parts of Wadström's description of Africa in his Essay draw on Sparrman's printed travel accounts (Wadström, 1794: 178). Sparrman is also listed as one of the subscribers to the Essay. Of the 285 subscribers, almost half had Swedish origins or connections; the remainder were British - among them William Wilberforce (1749-1833) and Joseph Banks (1743-1820) (Nelson, 1998: 86).

Swedenborg provided a point of transnational Anglo-Swedish intellectual connection among the less prominent subscribers. Wadström was engaged in setting up the Church of New Jerusalem congregation in London. Sparrman and Wadström both moved in Swedish Swedenborgian circles, which at the time encompassed some of the more radical and utopian thinkers in late-18th-century Europe. Another Swede, the mineralogist August Nordenskiöld (1754-92) had found a map of Africa among Swedenborg's papers that indicated where to find those peoples with the highest spiritual capacity. Any project involving Africa had the additional benefit of providing an opportunity for the followers of Swedenborg to establish links with these Africans. The notion of the deeprooted corruption of Europe was another strand of Swedenborgianism that inspired believers to search for alternative places to settle. The Sierra Leone Company, operating out of Freetown, and the Bulama project, both initiated in the 1790s, attracted members of the London-based Church of New Jerusalem. ${ }^{5}$

Wadström did, however, address a much wider audience than Swedenborg's followers, applying theories at the centre of the new political economy. As Jonas Ahlskog has convincingly argued, Wadström's Essay was framed by Scottish political economic thought, which gave force to his advocacy of the abolition of the transatlantic slave trade (Ahlskog, 2010: 148-63). As the papers by Sebastiani and Van Gent in this issue also suggest, the Atlantic slave trade was a key context for the application of both Scottish stadial theory and notions of savagery. Abolitionism gained momentum in the wake of the expanding trade in slaves and slave-produced goods across the Atlantic. Only in the following century - first in 1807, with the British ban on slave trading, and eventually in the ban on slavery itself across the Atlantic world - did the movement gain any significant victories. By then, the European colonization of Africa was in progress, with Sierra Leone becoming Britain's first crown colony in Africa in 1808. 
Wadström's Essay contained descriptions of the early European colonization of Africa, taking into account its connection to both the East India trade and the Atlantic trade, and referring to activities under Portuguese, Dutch, French, and Danish flags, but also discussed the ongoing Swedish plans. The framework of the analysis was inspired by the leading figures of the Scottish Enlightenment, including Lord Kames, David Hume, and Adam Smith. Stadial theory was a central pillar of Wadström's text, another being the author's strong emphasis on free labour, echoing Smith's Wealth of Nations. Critiques of monopolies, such as those held by the East India Companies or the 'Lofty Asiatic plunderers of Leadenhall-street' are other clues indicating the extent to which the dogma of free trade inspired Wadström (Wadström, 1794: 69). One indication of the pervasive influence of these ideas, as Ahlskog points out, lies in Wadström's discussions of the pros and cons of the division of labour. Africans, he argued, were similar to the peasants in northern Europe ('in Sweden, Norway, Scotland, \&c'), who made and repaired their own tools, furniture, and clothes and who were more 'intelligent' than those who spent their lives 'forging horse-shoes, making nails, or burnishing buttons' (ibid.: 17). Assigned 'one simple operation', the latter group became 'a kind of living machine' (ibid.: 17-18). Africans, like northern European peasants, were not (yet) 'stupid mechanics', however; in this respect they were also ripe for the changes Wadström's colonization plans implied (ibid.: 18). This plan involved encouraging, to no small degree, 'natural production' in the form of agriculture (ibid.: 72). We can trace the influence of physiocracy in these discussions; Wadström spent several pages of his Essay criticizing the aim of 'accumulat[ing] money' and 'imaginary denominations of pounds, livres, rix-dollars'. For him, promoting labour and agricultural products for trade and work was the true measure of wealth (ibid.: 71-2, Ambjörnsson, 1981: 123-31).

What distinguishes Wadström's account is the way in which he envisioned that the process of civilization in Africa would be brought about, namely by the introduction of luxuries. A very basic formula described the dynamic of change: 'new objects' would evoke 'new desires'; this would stimulate 'faculties' that until now had 'lain dormant, merely for the want of exercise' among the Africans (Wadström, 1794: 20). Scottish stadial theory was in evidence here too, although of course consumption and luxuries were by no means new topics in 18th-century Sweden (Runefelt, 2015). The promotion of trade in new goods would lead to the development of new mores and manners. Luxury would make Africans 'relish the comforts of civilized life' and experience 'enjoyments beyond the necessaries of mere animal life' and 'animal instinct' (Wadström, 1794: 20, 22-3). The demand for luxuries would further domestic production and trade, providing for the development of alternative economies to the prevailing slave trade. Herein lay the means by which one could 'make a rude people happy' (ibid.: 256).

As Ahlskog points out, Wadström is aware of the potentially corrupting influence of luxury informed by his knowledge of Scottish Enlightenment writers. For example, he carefully invokes Hume to distinguish between luxuries that generated 'effeminacy' and those that caused 'innocent enjoyment' and, in the longer term, stimulated 'industry' and 'improvement' (Ahlskog, 2010: 160-2; Wadström, 1794: 20; see also Wadström, 1795: 344-5). The way around this problem was to guide African consumption by carefully selecting which luxuries to provide for them. Hitherto, this process had been unregulated, leading to an extensive trade in 'gunpowder and brandy' (Wadström, 1794: 20). In 
contrast, Wadström's project implied a 'Government' of Europeans who were 'empowered to regulate and control the use of luxuries' (Wadström, 1795: 234). The locus of this control would be a 'sample room' or 'public retail shop', in which 'specimens of all approved articles of luxury should be displayed' (ibid.: 234). The Freetown colony and the Sierra Leone Company were already on the right track by 'furnishing articles rather better, and somewhat different in kind, from those generally sent to Africa' (ibid.: 56). The impact was visible, he optimistically argued, in that natives employed by the Company had chosen to spend their wages buying clothes. Their use of 'hats and jackets' and trousers of 'a better quality' distinguished them from other natives, showing that they were 'evidently disposed to copy the Europeans' (ibid.: 59). For all its evil, the slave trade had given Africans a taste for 'European goods', to the extent that some were now regarded as 'necessaries' in life (ibid.: 104). This provided the foundation for the next stage of civilization. Africans, 'excited to use articles manufactured in the European manner', needed to be taught to fabricate such objects 'with their own hands', opening up the 'path of honest industry' and independence from a 'precarious supply of foreign goods, baubles and trash' (Wadström, 1794: 102).

The equation involving luxury, consumption, domestic production, and civilization incorporated various strands that had been at the heart of many 18th-century discussions of luxury. What marked Wadström's account was the extent to which globalization of trade in consumer goods was used both to explain history and to point towards the future. The East India Companies had historically neglected Africa en route to Asia, because the Africans, not having advanced so far in the arts as the East Indians, nor having at that stage discovered such quantities of precious metals as the Americans, could not immediately supply the European demand for these desirable products, which the commerce of the East offered in comparable abundance (Wadström, 1794: 3). Meanwhile, the expansion westwards, across the Atlantic, created considerable demand for labour, since the 'aborigines' of America could not 'endure the toils imposed on them by their new masters'; the resulting trade in African slaves, however, had become 'the grand obstacle to [the Africans'] improvement' (ibid.: 3-4).

Wadström's solution entailed integrating Africans in the global trade of consumer goods - again, a risky, albeit necessary, path to venture. This meant accepting the fact that 'mankind generally set the greatest value on things distant and difficult to be obtained'; remoteness acted as a 'fog' in that 'it confuses objects, and lends them a magnitude that does not belong to them; and thus fascinates and misleads men of warm imaginations, often to their injury, sometimes to their ruin' (Wadström, 1794: 5). Africa was in a good position to take advantage of this, being relatively close to European markets thirsty for exotic goods. African sugar, produced by free labourers for export to European and American markets, provided one potential export crop (ibid.). There were numerous other African products that could be commercially viable to introduce to European markets, replacing products from the Atlantic and Asian areas, including African pepper 'of the same quality' as that of East India and African cotton likewise 'near equal' to the Asian alternatives (ibid.: 38, 36). African indigo was near equal to Guatemalan in quality, and African gum was 'equal in all respects' to Indian rubber (ibid.: 36-7). In addition, there were 'ostrich feathers', hippo and elephant 'teeth', and ivory to be had, all exclusive or near-exclusive to Africa (ibid.: 34$){ }^{6}$ 
The centrality of goods was further reinforced by Wadström's references to African products he brought to Europe. These constituted material proof of the potential for connecting the European craving for new products with the skills to make them in Africa. What was needed were 'instructions' and 'encouragements' that would turn Africans into 'excellent artizans', a conclusion drawn by 'English manufacturers' who had seen samples of products Wadström had brought home (Wadström, 1795: 195). While the 1790s saw the development by British abolitionists of various movements aimed at boycotting West Indian sugar, what Wadström was envisioning was more consumption as the primary way forward (Midgley, 1996). The necessary condition was a continuous increase in the globalization of trade and exposure to new products, stimulating the universal human desire for variety and comfort.

\section{Concluding remarks}

Sparrman and Wadström both travelled to Africa, and also moved in the same Swedenborgian and abolitionist circles. Nonetheless, addressing different audiences from different scholarly outlooks, they diverged radically in how they contextualized the savage. In the politicized Royal Swedish Academy of Sciences, whose members revered the arts and sciences as useful to the state, and whose patron Gustav III harboured colonial ambitions, a static and hierarchical understanding of human communities was at the forefront. Sparrman's oration interpreted non-European peoples in overwhelmingly negative terms. His interpretation was stadial insofar as he was able to account for the diversity of human manners and modes of subsistence, but his analysis lacked dynamism. His oration was concerned more with cataloguing human diversity than in accounting for human development. In this respect, Sparrman viewed savages as a Linnaean naturalist, and while he made reference to 'civilizing' the 'savages', this was predominantly a theoretical possibility and a rhetorical flourish.

To Wadström, addressing a transnational audience as a political economist above all, the globalizing dynamics of trade and its effect on production and consumption were the keys to both understanding history and changing the fate of African 'savages'. Drawing on the Smithian definition of luxury in particular enabled Wadström to present stadial theory as a plan for social development. Luxuries in the form of new objects would evoke new faculties, a relish for comforts and enjoyments, and would thus spur industry in agriculture and manufacturing. In place of Sparrman's static stadial vision, Wadström gestured towards a much more dynamic view of human social development driven by the global trade in luxury goods. The impact of luxury and trade promised the rapid advancement of the savage, in contrast to Sparrman's vision of a stratified world in which the savage remained behind and below the civilized Europeans. The differences between their analyses were the result of the contrast between Sparrman's predominantly natural historical framework presented for a mostly national audience and Wadström's more political economic interpretation for a transnational readership. Together, they help to demonstrate how a stadial account of African 'savagery' could accommodate divergent ends: a hierarchical ordering of human diversity that buttressed Europe's ascendency and a more fluid, globalizing civilization connected through luxury and consumption. 


\section{Declaration of conflicting interests}

The authors declared no potential conflicts of interest with respect to the research, authorship, and/ or publication of this article.

\section{Funding}

The authors received no financial support for the research, authorship, and/or publication of this article.

\section{ORCID iD}

Mathias Persson (D) https://orcid.org/0000-0003-3965-520X

\section{Notes}

1. Both Sparrman and Wadström have been subjects of various studies, noticeably those by Broberg, Dunér and Moberg (2012); Hagen (1946); Nelson (1998); and Pratt (1992).

2. Unless otherwise stated, all translations from Swedish sources are the authors' own.

3. On the attacks on Rousseau in the Royal Academy of Sciences, see Persson (2017).

4. On the issue of the potential for progress of 'savages' in Enlightenment debates, see Sebastiani (2013).

5. For discussions of the utopian and romantic dimension of Swedenborgianism, see Ambjörnsson (1981) and Coleman (2005).

6. The leading abolitionist Thomas Clarkson (1760-1846) compiled similar lists of potential African goods; see Schwartz (2017: 8-14).

\section{References}

Ahlskog, J. (2010) 'The Political Economy of Colonisation: Carl Bernhard Wadström's Case for Abolition and Civilisation', Sjuttonhundratal 7: 146-67.

Alm, M. (2002) Kungsord i elfte timmen: Språk och självbild i det gustavianska enväldets legitimitetskamp 1772-1809 [Royal Words at the Eleventh Hour: Language and Self-Image in the Struggle for Legitimacy of Gustavian Absolutism, 1772-1809]. Stockholm: Atlantis.

Ambjörnsson, R. (1981) Det okända landet: Tre studier om svenska utopister [The Unknown Country: Three Studies of Swedish Utopians]. Stockholm: Gidlund.

Andersson Burnett, L. and Buchan, B. (2018) 'The Edinburgh Connection: Linnaean Natural History, Scottish Moral Philosophy and the Colonial Implications of Enlightenment Thought', in H. Hodacs, K. Nyberg and S. Van Damme (eds) Linnaeus, Natural History and the Circulation of Knowledge. Oxford: Voltaire Foundation, pp. 161-86.

Beinart, W. (1998) 'Men, Science, Travel and Nature in the Eighteenth and Nineteenth-Century Cape', Journal of Southern African Studies 24(4): 775-99.

Berg, M. and Eger, E. (2003) 'The Rise and Fall of the Luxury Debates', in M. Berg and E. Eger (eds) Luxury in the Eighteenth Century: Debates, Desires and Delectable Goods. Basingstoke: Palgrave Macmillan, pp. 7-27.

Broberg, G., Dunér, D. and Moberg, R., eds (2012) Anders Sparrman: Linnean, världsresenär, fattigläkare [Anders Sparrman: Linnaean, Globetrotter, Physician of the Poor]. Uppsala: Svenska Linnésällskapet.

Buchan, B. and Heath, M. (2006) 'Savagery and Civilization: From Terra Nullius to the "Tide of History", Ethnicities 6(1): 5-26. 
Campbell, I. C. (1980) 'Savages Noble and Ignoble: The Preconceptions of Early European Voyagers in Polynesia', Pacific Studies 4: 45-59.

Coleman, D. (2005) Romantic Colonization and British Anti-Slavery. Cambridge: Cambridge University Press.

Crais, C. C. (1991) 'The Vacant Land: The Mythology of British Expansion in the Eastern Cape, South Africa', Journal of Social History 25(2): 255-75.

Ellingson, T. (2001) The Myth of the Noble Savage. Berkeley: University of California Press.

Hagen, E. (1946) En frihetstidens son: Carl Bernhard Wadström. Bergsvetenskapsman, forskningsresande, filantrop [A Son of the Age of Liberty: Carl Bernhard Wadström: Mining Engineer, Research Traveller, Philanthropist]. Stockholm: Gothia.

Hont, I. (2006) 'The Early Enlightenment Debate on Commerce and Luxury', in M. Goldie and R. Wokler (eds) The Cambridge History of Eighteenth-Century Political Thought. Cambridge: Cambridge University Press, pp. 377-418.

Jacques, T. C. (1997) 'From Savages and Barbarians to Primitives: Africa, Social Typologies, and History in Eighteenth-Century French Philosophy', History \& Theory 36(2): 190-215.

Laine, M. (1998) 'En Minerva för vair Nord': Lovisa Ulrika som samlare, uppdragsgivare och byggherre ['A Minerva for Our North': Lovisa Ulrika as Collector, Employer and Building Proprietor]. Stockholm: M. Laine.

Lindroth, S. (1967) Kungl. Svenska Vetenskapsakademiens historia 1739-1818: Vol. 1, Part 1. Tiden intill Wargentins död (1783) [The History of the Royal Academy of Sciences, 17391818: Vol. 1, Part 1. The Time Until Wargentin's Death (1783)]. Stockholm: Kungl. Vetenskapsakademien.

Lovejoy, A. O. (1936) The Great Chain of Being: A Study of the History of an Idea. Cambridge, MA: Harvard University Press.

Lucas, J. S. (2000) 'The Course of Empire and the Long Road to Civilization: North American Indians and Scottish Enlightenment Historians', Explorations in Early American Culture 4: 166-90.

Meek, R. L. (1976) Social Science and the Ignoble Savage. Cambridge: Cambridge University Press.

Midgley, C. (1996) 'Slave Sugar Boycotts, Female Activism and the Domestic Base of British Anti-Slavery Culture', Slavery \& Abolition 17(3): 137-62.

Nelson, P. K. (1998) Carl Bernhard Wadström: Mannen bakom myten [Carl Bernhard Wadström: The Man Behind the Myth]. Norrköping: Föreningen Gamla Norrköping.

Nordenskiöld, U. (1776) Afhandling om nyttan för Sverige af handel och nybyggen i Indierna och pa Africa [Treatise on the Utility to Sweden of Trade With and Settlements in the Indies and Africa]. Stockholm: Peter Hesselberg.

Nyberg, K. (2012) 'Anders Sparrman - konturer av en livshistoria' [Anders Sparrman - Contours of a Biography], in G. Broberg, D. Dunér and R. Moberg (eds) Anders Sparrman: Linnean, världsresenär, fattigläkare [Anders Sparrman: Linnaean, Globetrotter, Physician of the Poor]. Uppsala: Svenska Linnésällskapet, pp. 13-34.

Ogden, D. T. (2012) 'Anders Sparrman and the Abolition of the British Slave Trade', in G. Broberg, D. Dunér and R. Moberg (eds) Anders Sparrman: Linnean, världsresenär, fattigläkare [Anders Sparrman: Linnaean, Globetrotter, Physician of the Poor]. Uppsala: Svenska Linnésällskapet, pp. 141-56. 
Pagden, A. (1993) European Encounters with the New World: From Renaissance to Romanticism. New Haven: Yale University Press.

Palmeri, F. (2008) 'Conjectural History and the Origins of Sociology', Studies in EighteenthCentury Culture 37: 1-21.

Persson, M. (2017) 'Det råa tillståndet: Vetenskapsakademien, vildarna och den koloniala världsordningen' [The Rude State: The Royal Academy of Sciences, the Savages, and the Colonial World Order], in J. Nell and A. Sjödin (eds) Kritik och beundran: Jean-Jacques Rousseau och Sverige 1750-1850 [Criticism and Admiration: Jean-Jacques Rousseau and Sweden 17501850]. Lund: ellerströms, pp. 125-48.

Pratt, M. L. (1992) Imperial Eyes: Travel Writing and Transculturation. London: Routledge.

Qvist, B. (1776) Tal, innehallande nägra anmärkningar öfver metall- och mineralvaror samt deras aftsättning [Oration, Comprising Some Comments about Metal and Mineral Commodities and Their Marketing]. Stockholm: Lange.

Roberts, M. J. D. (1998) 'The Concept of Luxury in British Political Economy: Adam Smith to Alfred Marshall', History of the Human Sciences 11(1): 23-47.

Robertson, W. (1777) The History of America (Vols 1-8). Dublin: Messrs Price et al.

Rönnbäck, K. (2013) 'Enlightenment, Scientific Exploration and Abolitionism: Anders Sparrman's and Carl Bernhard Wadström's Colonial Encounters in Senegal, 1787-1788 and the British Abolitionist Movement', Slavery \& Abolition 34(3): 425-45.

Runefelt, L. (2015) Att hasta mot undergaingen: Anspraik, flyktighet, förställning i debatten om konsumtion i Sverige 1730-1830 [To Haste Towards Destruction: Claims, Transience, Dissimulation in the Debate About Consumption in Sweden 1730-1830]. Lund: Nordic Academic Press.

Sebastiani, S. (2013) The Scottish Enlightenment: Race, Gender, and the Limits of Progress, trans. J. Carden. New York: Palgrave Macmillan.

Sloan, P. (1995) 'The Gaze of Natural History', in C. Fox, R. Porter and R. Wokler (eds) Inventing Human Science: Eighteenth-Century Domains. Berkeley: University of California Press, pp. 112-51.

Schwarz, S. (2017) “"A Just and Honourable Commerce”: Abolitionist Experimentation in Sierra Leone in the Late Eighteenth and Early Nineteenth Centuries', African Economic History 45(1): $1-45$.

Sörlin, S. and Fagerstedt, O. (2004) Linné och hans apostlar [Linnaeus and His Apostles]. Stockholm: Natur och kultur.

Sparrman, A. (1778) Tal, om den tilväxt och nytta, som vetenskaperne i allmänhet, särdeles natural-historien, redan vunnit och ytterligare kunna vinna, genom undersökningar i Söderhafvet [Oration on the Growth and Utility That the Sciences in General, Particularly Natural History, Have Already Attained and Could Further Attain Through Investigations in the South Seas]. Stockholm: Lange.

Sparrman, A. (1783-1818) Resa till Goda Hopps-udden, södra pol-kretsen och omkring jordklotet, samt till hottentott- och caffer-landen, aren 1772-76: Vol. 1 [A Voyage to the Cape of Good Hope, Towards the Antarctic Polar Circle, Round the World and to the Country of the Hottentots and the Caffres, From the Year 1772-76: Vol. 1]. Stockholm: Anders J. Nordström.

Sprinchorn, C. (1923) 'Sjuttonhundratalets planer och förslag till svensk kolonisation i främmande världsdelar' [The Plans and Suggestions During the Eighteenth Century Regarding Swedish Colonization of Alien Parts of the World], Historisk tidskrift 43: 109-62. 
Tandefelt, H. (2008) Konsten att härska: Gustaf III inför sina undersaitar [The Art of Ruling: Gustaf III in Front of His Subjects]. Helsinki: Svenska litteratursällskapet i Finland.

Wadström, B. (1794-1795) An Essay on Colonization, Particularly Applied to the Western Coast of Africa, With Some Free Thoughts on Cultivation and Commerce: And Also Brief Descriptions of the Colonies Already Formed, or Attempted, in Africa, Including Those of Sierra Leone and Bulama (Vols 1-2). London: Darton and Harvey.

Waller, S. M. (1953) 'Det svenska förvärvet av S:t Barthélemy: Huvuddragen av de svensk-franska förhandlingarna och parternas syften' [The Swedish Acquisition of Saint-Barthélemy: The Main Outlines of the Swedish-French Negotiations and the Aims of the Parties], Historisk tidskrift 3: 231-55.

Wargentin, P. W. (1764) 'Svar, gifvet på Kongl. Vetensk. Academiens vägnar' [Answer, on Behalf of the Royal Academy of Sciences], in P. J. Bergius, Tal, om kalla bad i gemen, och Loka badningar i synnerhet [Oration, on Cold Baths in General, and Loka Baths in Particular]. Stockholm: Lars Salvius, pp. 109-12.

Weiss, H. (2013) 'A Divided Space: Subjects and Others in the Swedish West Indies during the Late-Eighteenth Century', in G. Rydén (ed.) Sweden in the Eighteenth-Century World: Provincial Cosmopolitans. Farnham: Ashgate, pp. 275-97.

Weiss, H. (2016) Slavhandel och slaveri under svensk flagg: Koloniala drömmar och verklighet $i$ Afrika och Karibien 1770-1847 [Slave Trade and Slavery Under Swedish Flag: Colonial Dreams and Reality in Africa and the Caribbean 1770-1847]. Stockholm: Atlantis.

Widmalm, S. (1990) Mellan kartan och verkligheten: Geodesi och kartläggning, 1695-1860 [Between the Map and Reality: Geodesy and Mapping, 1695-1860]. Uppsala: Uppsala University.

Wolloch, N. (2011) 'The Civilizing Process, Nature, and Stadial Theory', Eighteenth-Century Studies 44(2): 245-59.

\section{Author biographies}

Hanna Hodacs is an associate professor at Dalarna University. She has previously worked as a research fellow at the University of Warwick, the Royal Swedish Academy of Sciences in Stockholm and Uppsala University.

Mathias Persson holds a PhD in the history of science and ideas. He is currently affiliated with the Department of Economic History at Uppsala University and the Department of Historical Studies at the University of Johannesburg. 